\title{
Effects of vitamin E deficiency on total polyunsaturated fatty acids in rats and chicks
}

\author{
By J. BUNYAN, A. T. DIPLOCK AND J. GREEN \\ Walton Oaks Experimental Station, Vitamins Ltd, Tadworth, Surrey
}

(Received 29 fuly 1966-Accepted 12 October 1966)

\begin{abstract}
1. The total polyunsaturated fatty acid (PUFA) content of tissues of vitamin E-deficient rats and chicks has been measured by the lipoxidase method.

2. Vitamin E deficiency did not depress total PUFA in rat liver, kidney, heart, spleen, brain, adrenal and adipose tissue during experimental periods up to 13 months.

3. Liver PUFA was not depressed by deficiency of vitamin $E$ and sclenium in rats at 9 weeks or 8 months of age.

4. Rats given a muscular dystrophy-producing diet (containing oxidized cod-liver oil) showed a severe depletion of PUFA in muscle, but not in kidney or adipose tissue.

5. Exudative diathesis induced in chicks by a deficiency of vitamin $E$ and Se did not depress liver PUFA.

6. It is considered that in vitamin E deficiency there is no general decrease in PUFA due to peroxidative loss. Changes of a more specific nature occur, as found by other workers.
\end{abstract}

The hypothesis that vitamin $\mathrm{E}$ acts mainly as a physiological antioxidant suggests that, in its absence, loss of many types of oxidizable substances may occur. Considerable importance has been attached, in this connexion, to the polyunsaturated fatty acids (PUFA), because of their chemical structure and because of their biochemical role in structural elements of the cell. Pritchard \& Singh (I960) found marked decreases $\left(50^{\circ}-75 \%\right)$ in the PUFA content of heart, liver, adrenals and plasma (but not brain) of vitamin E-deficient rats, although Bernhard (I958) had previously reported no great change in PUFA content of brain, liver, lung, spleen and depot fat when vitamin $\mathrm{E}$-deficient female rats were given vitamin $\mathrm{E}$.

Our recent studies on the metabolism of $\left[{ }^{14} \mathrm{C}\right] \alpha$-tocopherol in the vitamin E-deficient rat (Green, Diplock, Bunyan, McHale \& Muthy, 1967) and chick (Diplock, Bunyan, McHale \& Green, 1967) led us to conclude that lipid peroxidation is not a causal process in the aetiology of vitamin $\mathrm{E}$ deficiency disease. Consequently, we would not expect there to be a general loss of tissue PUFA in the deficient animal, contrary to the findings of Pritchard \& Singh (1960) and in agreement with Bernhard (1958).

In this paper we describe our experiments on PUFA in vitamin E-deficient tissues.

\section{EXPERIMENTAL AND RESULTS}

\section{Analytical methods}

Extraction and saponification of tissue lipids (method I). An homogenate (200 $\mathrm{mg}$ tissue $/ \mathrm{ml} \circ \cdot \mathrm{I} \mathrm{M}$-phosphate buffer, $\mathrm{pH} 7.4$ ) was made in a glass homogenizer, with a nylon pestle rotating at about $1000 \mathrm{rev} / \mathrm{min}$. An equal volume of $35 \%(\mathrm{w} / \mathrm{v})$ trichloroacetic acid solution was then added to precipitate proteins. The suspension was shaken twice with an equal volume of a mixture $(r: I, v / v)$ of light petroleum (b.p. 
$40^{\circ}-60^{\circ}$ ) and ethanol and three times with an equal volume of light petroleum. The combined extracts were filtered through cotton-wool. A sample was evaporated to dryness under reduced pressure in $\mathrm{N}_{2}$. Tissue lipids $\left(5^{-20} \mathrm{mg}\right)$ were then saponified by adding $0.75 \mathrm{ml}$ of aqueous ethanol $(67 \%, \mathrm{v} / \mathrm{v})$ containing $\mathrm{KOH}(20 \%, \mathrm{w} / \mathrm{v})$. The flask was warmed slightly to aid mixing, flushed with $\mathrm{N}_{2}$, stoppered and left in the dark at room temperature for $17 \mathrm{~h}$.

Extraction and saponification of tissue lipids (method 2). Tissues were extracted by the method of Folch, Lees \& Stanley (1957). Tissue was blended in 19 volumes of a mixture of chloroform and methanol $(2: \mathrm{r}, \mathrm{v} / \mathrm{v})$ in a top-drive homogenizer at about I000 rev/min for I min, the mixture being cooled in crushed ice. The solvent mixture was gassed with $\mathrm{N}_{2}$ before use and $\mathrm{N}_{2}$ was also passed through the homogenizer goblet before and during homogenization. The extract was clarified by centrifugation and (if necessary) by filtration through glass wool. An aqueous wash to remove nonlipid material (Folch et al. 1957) was not found necessary; in a test, we found that washing did not affect the PUFA determination. Saponification was carried out as described for method $\mathrm{I}$, except that $\mathrm{I} \cdot 5 \mathrm{ml}$ saponification mixture was used for $5^{-20}$ $\mathrm{mg}$ tissue lipid. An atmosphere of $\mathrm{N}_{2}$ was maintained throughout the whole procedure.

Determination of PUFA. Saponified lipids $\left(5^{-20} \mathrm{mg}\right)$ were diluted to a suitable strength for testing in I M-borate buffer, $\mathrm{pH} 99^{\circ}$. PUFA was determined in this solution by the lipoxidase method of MacGee (1959). The concentration of the solution of lipoxidase (Koch-Light Laboratories Ltd) in $0.2 \mathrm{M}$-borate buffer, $\mathrm{pH} 9.0$, was usually about $0.2 \mathrm{mg} / \mathrm{ml}$, but the strength was adjusted so that reaction with linoleic acid was complete within $5 \mathrm{~min}$. A portion $(0 \cdot 2-0 \cdot 4 \mathrm{ml})$ of enzyme solution was added with stirring to $3 \mathrm{ml}$ of test solution in a cuvette and its optical density at $234 \mathrm{~nm}$ was compared to a blank consisting of $3 \mathrm{ml}$ test solution containing boiled enzyme solution. Each solution of saponified lipid was tested in duplicate.

Standard solutions. The test procedure was calibrated with standard solutions of linoleic acid (95\% pure; Koch-Light Laboratories, Ltd) or methyl linoleate (Sigma, Ltd), after saponification.

Determination of total lipid. The total lipid content of the extract was measured by evaporating a sample to constant weight. When method 2 was used, the sample was first washed with (0.73\%) $\mathrm{NaCl}$ solution (Folch et al. 1957).

Recovery test. In one test, the recovery of methyl linoleate added to rat liver was found to be $109 \%$ (method 2 ).

\section{Animal experiments}

The rats used were of the Norwegian hooded strain and the chicks were Rhode Island Red $\times$ Light Sussex cockerels.

Expt I. Sixteen 5-week-old male rats were allocated at random to two groups and given either the vitamin E-deficient diet A40Y (Bunyan, McHale \& Green, I963) or that diet supplemented with D- $\alpha$-tocopheryl acetate, $100 \mathrm{ppm}$. Female rats (two per group) were reared from ${ }_{4} 4$ days old either on diet $\mathrm{A}_{\text {Io }} \mathrm{Y}_{3}$ (Bunyan, McHale \& Green, $\mathrm{r}_{96} 6_{3}$ ) or diet $\mathrm{A} \mathrm{roY}_{3}+\mathrm{E}$ (Bunyan, McHale \& Green, r963). The rats were all killed and tested at 5 months of age. The results (Table I) show that no depression 
of liver PUFA was induced by vitamin $\mathrm{E}$ deficiency over a period twice as long as that used by Pritchard \& Singh (I960). These authors reported a decrease of $61 \%$ in liver in 62 days.

Table I. Expt $\mathrm{x}$. Effects of vitamin E-deficiency on polyunsaturated fatty acid $(P U F A)$ content of rat liver

\begin{tabular}{|c|c|c|c|c|c|c|}
\hline \multirow{2}{*}{\multicolumn{3}{|c|}{ Liver PUFA content (mg/g) }} & \multirow{2}{*}{\multicolumn{2}{|c|}{ Liver wt (g) }} & \multicolumn{2}{|c|}{ Liver lipid (\%) } \\
\hline & & & & & & Normal \\
\hline & Deficient rats* & Normal rats* & Deficient rats* & Normal rats* & & rats* \\
\hline $\begin{array}{l}\text { Iale } \\
\text { emale }\end{array}$ & $\begin{array}{l}3.4 \pm 0.5(4) \dagger \\
\text { II.7† }\end{array}$ & $\begin{array}{l}3.2 \pm 0.4(4)\} \\
10.1 f\end{array}$ & $\begin{array}{l}8 \cdot 4 \pm 1 \cdot 0(4) \dagger \\
5 \cdot 8\end{array}$ & $\begin{array}{l}8.8 \pm 0.7) \\
6.7\end{array}$ & $-7 \cdot 6$ & $\overline{4 \cdot 9}$ \\
\hline
\end{tabular}

* The vitamin E-deficient diets $\mathrm{A}_{4} \circ \mathrm{Y}$ (male rats) and $\mathrm{A}_{10} \circ 3$ (female rats) and these diets with supplements of vitamin $E$ were used. See text (p. 2I8) for details of diets. The rats were 5 months old when tested.

$\dagger$ Means with standard deviations of tests carried out on rat livers combined in pairs (number of pairs shown in parentheses). Extraction method $\mathrm{r}$ (p. 217) was used.

$\ddagger$ For each group, an extract from a sample of two rat livers combined was prepared by extraction method 2 (p. 218).

Expt 2. In this experiment, we investigated the long-term effects of vitamin $\mathrm{E}$ deficiency in female rats. Rats were reared from 14 days to 13 months old on diet $\alpha_{3}$ (Bunyan, Green, Diplock \& Robinson, I967a) or on that diet supplemented with $D-\alpha$-tocopheryl acetate, I00 ppm. Some rats, as indicated in Table 2, were pregnant and were killed after $14-17$ days of gestation. The vitamin E-deficient rats were from a larger group of animals that were all found to be sterile in a gestation-resorption test (Bunyan et al. 1967a). The eight vitamin E-deficient rats studied here had resorbed their litters and the rats given dietary vitamin $\mathrm{E}$ were undergoing a normal pregnancy, with about eight live young each. This marked difference in vitamin $E$ status had no effect on the PUFA content of the seven tissues studied (Table 2). Nonpregnant normal rats were also studied; there was little effect of pregnancy on the PUFA content of the tissues. The apparent decrease in PUFA content of adrenals from deficient pregnant rats may be significant, but a similar value was found for normal non-pregnant rats.

Expt 3. This experiment was an attempt to induce muscular dystrophy in rats by giving them one of the basal diets described by Century \& Horwitt (1960). Male rats, at 3 o days old, were given a vitamin E-deficient diet with the percentage composition: casein ('low vitamin content'; Genatosan Ltd) 25, salt mixture (Bunyan, Green \& Diplock, 1963) 5, vitamin mixture (Bunyan, Green \& Diplock, 1963) 0.4 , choline dihydrogen tartrate 0.24 , glucose $6 \mathrm{I} \cdot 4$ and cod-liver oil (oxidized to a peroxide value of about 50 ) 8. Vitamin $\mathrm{A}, 20$ i.u./g, vitamin $\mathrm{D}_{3}, 5$ i.u./g (both as stabilized powders) and menaphthone, $0.15 \mu \mathrm{g} / \mathrm{g}$, were also added. Some rats also received a dietary supplement of D- $\alpha$-tocopheryl acetate, $200 \mathrm{ppm}$. After I2 months the PUFA content of leg muscle was severely depleted to about $20 \%$ of that of control rats given vitamin E. However, as is shown by the lack of effect in kidney and adipose tissue (Table 3), this may not be a general effect of vitamin $\mathrm{E}$ deficiency. 
Expt 4. Rats were given a vitamin E-deficient diet until 30 days old and then divided at random, with sex and litter-mate control, into groups and given a baker's yeast necrogenic diet (Bunyan, Green \& Diplock, I963) or that diet supplemented with $\mathrm{Se}, 0.05 \mathrm{ppm}$ as sodium selenite, or $\mathrm{D}-\alpha$-tocopheryl acetate, $20 \mathrm{ppm}$ or both Se and

Table 2. Expt 2. Effects of vitamin $E$ deficiency on polyunsaturated fatty acids (PUFA) in tissues of female rats

(Extraction method 2 (p. 218) was used)

\begin{tabular}{|c|c|c|c|}
\hline \multirow[b]{2}{*}{ Tissue } & \multirow{2}{*}{$\begin{array}{l}\text { Deficient rats } \\
\text { (pregnant)* }\end{array}$} & \multicolumn{2}{|c|}{ Normal rats $\dagger$} \\
\hline & & Pregnant & Non-pregnan \\
\hline \multicolumn{4}{|c|}{ Tissue PUFA (mg/g) $\ddagger$} \\
\hline Liver & I2:I & I I ‘ 9 & $12 \cdot 5$ \\
\hline Kidney & $10: 3$ & $8 \cdot 5$ & $9 \cdot 6$ \\
\hline Heart & II 5 & $8 \cdot 4$ & $12 \cdot 1$ \\
\hline Spleen & $5 \cdot 5$ & $5 \cdot 4$ & $5 \cdot 0$ \\
\hline Brain & $12 \cdot 0$ & 12.5 & II·7 \\
\hline Adrenal & $27 \cdot 4$ & $39^{\circ} 9$ & $26 \cdot 8$ \\
\hline Adipose tissue§ & $3 x \cdot 4$ & $32 \cdot 7$ & $3 I \cdot I$ \\
\hline \multicolumn{4}{|c|}{ Tissue lipid $(\%) \downarrow$} \\
\hline Liver & $8 \cdot 4$ & $8 \cdot 6$ & $7 \cdot 4$ \\
\hline Kidney & $6 \cdot 5$ & $8 \cdot 5$ & $6 \cdot 5$ \\
\hline Heart & $5 \cdot 2$ & $3 \cdot \overline{8}$ & $5 \cdot 2$ \\
\hline Spleen & $4 \cdot 4$ & $3 \cdot 5$ & 43 \\
\hline Brain & $12 \cdot 2$ & II $\cdot 3$ & I I.6 \\
\hline Adrenal & $26 \cdot 5$ & $26 \cdot I$ & $30 \div 4$ \\
\hline Adipose tissue & $94 \cdot 3$ & $84 \cdot 2$ & 93.5 \\
\hline \multicolumn{4}{|c|}{ Tissue wt (g) } \\
\hline Liver & $8 \cdot 75$ & $8 \cdot 17$ & $7 \cdot 13$ \\
\hline Kidney & 0.83 & 0.76 & $0.5 \mathrm{I}$ \\
\hline Heart & 0.72 & 0.70 & 0.72 \\
\hline Spleen & 0.95 & $0.8 r$ & 0.57 \\
\hline Brain & $\mathrm{I} \cdot 36$ & $\mathbf{I} \cdot \circ 9$ & $I \cdot 35$ \\
\hline Adrenal & 0.02 & 0.02 & 0.017 \\
\hline Adipose tissue & - & $-\cdots$ & - \\
\hline
\end{tabular}

* Eight I3-month-old rats that had been given the vitamin E-deficient diet $\alpha_{3}$ (see p. 2r9). They were $14-17$ days pregnant when tested.

+ Seven 13-month-old rats that had been given diet $\alpha_{3}$ with vitamin E, roo ppm (see p. 219). Three of them were $14-17$ days pregnant when tested.

I The value given is the mean of several tests on tissues combined for analysis.

$\S$ Mainly peri-renal and mesenteric.

Table 3. Expt 3. Effects of vitamin E deficiency on polyunsaturated fatty acids (PUFA) in tissues of male rats given the test diets until $\mathrm{I} 3$ months old

(Tissues were taken from one rat per group and extracted by method 2 (p. 2 r 8 ). The result given for each tissue is the mean of several tests of the extract)

$\begin{array}{lccc}\text { Addition to basal diet* } & \text { Kidney } & \begin{array}{c}\text { Adipose } \\ \text { tissue } \dagger\end{array} & \text { Leg muscle } \\ \text { None } & 7 \cdot 2 & 7 \mathbf{r} & \text { I.I } \\ \text { Vitamin E, 200 ppm } & 6 \cdot 8 & 64 & 5 \cdot 3\end{array}$

* Containing $25 \%$ casein and $8 \%$ oxidized cod-liver oil (peroxide value $=50$ ), see (p. $2 \times 9$ ).

$\uparrow$ Epididymal, peri-renal and mesenteric fat deposits. 
vitamin $\mathrm{E}$. They were tested at 8 weeks old. The rats given the necrogenic diet showed $92 \%$ incidence of liver necrosis, but there was no depression of the PUFA content of the liver (Table 4 ).

Table 4. Expts 4-6. Effects of selenium and vitamin $E$ on polyunsaturated fatty acids ( $P U F A)$ in rat tissues

(In all these tests, rats were given a basal necrogenic diet, deficient in Se and vitamin $\mathrm{E}$ (see pp. 220, 221 for details). Expt 4: At 8 weeks old, pairs of rat livers (number shown in parentheses) were combined and a sample of each pair was extracted by method I (p. 2I 7 ). Two samples of each extract were saponified and tested. Results are given as means with standard deviations. Expt 5: at 10 weeks old, livers of one male and one female rat per group were combined and a sample of each pair was extracted by method 2 (p. 2 i 8 ). Three samples of each extract were saponified and tested. Expt 6: These rats were 8 months old when tested, those finally receiving the basal, necrogenic, diet having been protected against liver necrosis by dietary vitamin $\mathrm{E}$ from 4 to 10 weeks old. Tissues of one female rat of each group were extracted by method 2 and two or three samples were saponified and tested)

\begin{tabular}{|c|c|c|c|c|c|}
\hline \multirow[b]{3}{*}{$\begin{array}{l}\text { Addition to } \\
\text { basal diet }\end{array}$} & \multicolumn{5}{|c|}{ PUFA content of tissue $(\mathrm{mg} / \mathrm{g})$} \\
\hline & \multirow[b]{2}{*}{$\begin{array}{l}\text { Expt } 4^{*} \\
\text { Liver }\end{array}$} & \multirow[b]{2}{*}{$\begin{array}{l}\text { Expt } 5 \\
\text { Liver }\end{array}$} & \multicolumn{3}{|c|}{ Expt 6} \\
\hline & & & Liver & Kidney & $\begin{array}{c}\text { Adipose } \\
\text { tissue } \dagger\end{array}$ \\
\hline None & $5 \cdot 0 \pm I \cdot I(9)$ & $12 \cdot 2$ & $9 \cdot 6$ & I 3.3 & 130 \\
\hline Sef & $3.9 \pm 0.6(4)$ & $12 \cdot 5$ & $I I \cdot I$ & $14 \cdot 8$ & II4 \\
\hline Vitamin E & $4.5 \pm 0.6(7)$ & I4. I & $12 \cdot 6$ & $I I \cdot I$ & I 35 \\
\hline Se $\ddagger$ and vitamin $\mathrm{E}$ & $4 \cdot 2 \pm 0.5(4)$ & - & - & - & - \\
\hline
\end{tabular}

* No. of pairs of rats is shown in parentheses.

$\dagger$ Mainly peri-renal and mesenteric.

$\ddagger$ Se, $0.05 \mathrm{ppm}$, as sodium selenite.

Expt 5. Rats were given a torula yeast necrogenic diet (Bunyan, Green, Diplock $\&$ Robinson, $1967 b$ ) from 14 to 30 days old, when they were divided at random into groups to receive the same diet or that diet supplemented with Se, $0.05 \mathrm{ppm}$ or $\mathrm{D}-\alpha$-tocopheryl acetate, I00 $\mathrm{ppm}$. They were tested at ro weeks of age. Only one of the two rats given the necrogenic torula yeast diet had visible necrosis, but the lesions occurred in over $90 \%$ of a larger group of rats studied at the same time. These findings confirm previous experience with these basal diets (Bunyan, Green \& Diplock, 1963; Bunyan et al. $1967 b$ ). However, in spite of this severe (and rapidly fatal) deficiency of vitamin $\mathrm{E}$ and Se, there was no depression of PUFA in the affected tissue (Table 4 ).

Expt 6. In this experiment we studied the effects of a longer time of depletion of vitamin $\mathrm{E}$ and Se. Rats were given the torula yeast necrogenic diet from $\mathrm{I}_{4}$ to 30 days old and then divided into groups to receive the necrogenic diet supplemented with either D- $\alpha$-tocopheryl acetate, roo ppm or Se, $0.05 \mathrm{ppm}$. At ro weeks old some of the rats receiving vitamin $\mathbf{E}$ were given the necrogenic diet again. The dietary supplements protected the rats against liver necrosis during the 4 -10 week period but when some rats were again given the unsupplemented diet, three of eight females and all of the seven males in this group died of liver necrosis before 8 months old. Survivors from all three groups were tested at 8 months old. Even the prolonged deficiency of 
vitamin $\mathrm{E}$ and $\mathrm{Se}$ induced in this experiment did not affect the PUFA content of liver, kidney and adipose tissue (Table 4 ).

Expts 7 and 8. In these experiments, we studied the effects of separate and combined deficiencies of Se and vitamin $\mathrm{E}$ on the PUFA content of chick liver. One-dayold chicks were given a basal exudate-producing diet containing torula yeast (Bunyan, Diplock, Edwin \& Green, I962) or that diet with supplements of Se, 0.15 ppm (as sodium selenite), D- $\alpha$-tocopheryl acetate, $50 \mathrm{ppm}$, Se and vitamin E, or DPPD $(N$, $N$-diphenyl-p-phenylenediamine), $250 \mathrm{ppm}$. The basal diet produced exudative diathesis in most of the chicks (Table 5). Dietary supplements of Se or vitamin E, or both, were completely protective, but DPPD was ineffective at $250 \mathrm{ppm}$. Far from there being a depletion of liver PUFA caused by the deficiency state, there was, in fact, a significant depression of PUFA in the livers of chicks given vitamin $\mathrm{E}$.

Table 5. Expts 7 and 8. Effects of Se, vitamin $E$ and $\mathrm{N}, \mathrm{N}^{\prime}$-diphenyl-p-phenylenediamine (DPPD) on polyunsaturated fatty acids ( $P U F A)$ in chick liver

(The basal diet contained torula yeast and was deficient in Se and vitamin E. Chicks were tested at $21-30$ days old)

\begin{tabular}{|c|c|c|c|c|c|c|}
\hline \multirow[b]{2}{*}{$\begin{array}{c}\text { Addition } \\
\text { to } \\
\text { basal } \\
\text { diet }\end{array}$} & \multicolumn{3}{|c|}{ Expt 7} & \multicolumn{3}{|c|}{ Expt 8} \\
\hline & $\begin{array}{c}\text { Incidence* } \\
\text { of } \\
\text { exudative } \\
\text { diathesis }\end{array}$ & $\begin{array}{l}\text { Liver } \\
\text { PUFA† } \\
(\mathrm{mg} / \mathrm{g})\end{array}$ & $\begin{array}{c}\text { Liver } \\
\text { wt } \neq(\mathrm{g})\end{array}$ & $\begin{array}{l}\text { Incidence* } \\
\quad \text { of } \\
\text { exudative } \\
\text { diathesis }\end{array}$ & $\begin{array}{l}\text { Liver } \\
\text { PUFA } \dagger \\
(\mathrm{mg} / \mathrm{g})\end{array}$ & $\begin{array}{c}\text { Liver } \\
\text { wtf (g) }\end{array}$ \\
\hline None & $12 / 16$ & $5 \cdot 3 \pm I \cdot 5(8)$ & $5 \cdot 3 \pm 0.7(8)$ & $12 / 12$ & $6 \cdot 3 \pm I \cdot 4(6)$ & $5.9 \pm I \cdot 0(6)$ \\
\hline $\begin{array}{l}\mathrm{Se}, \mathrm{o} \cdot \mathrm{I}_{5} \\
\mathrm{ppm}\end{array}$ & $0 / 16$ & $5 \cdot 3 \pm I \cdot 8(8)$ & $6 \cdot 1 \pm I \cdot 2(8)$ & $0 / 13$ & $4.9 \pm 0.8(4)$ & $7 \cdot 5 \pm 1 \cdot 4(6)$ \\
\hline $\begin{array}{l}\text { Vitamin } \mathrm{E} \text {, } \\
50 \mathrm{ppm}\end{array}$ & $0 / 15$ & $4.2 \pm 0.7(8) \S$ & $5 \cdot 5 \pm I \cdot 3(8)$ & - & - & - \\
\hline $\begin{array}{l}\text { Se and } \\
\text { vitamin } E\end{array}$ & $0 / 18$ & $4 \cdot 6 \pm I \cdot 3(8)$ & $6 \cdot 4 \pm I \cdot I(8)$ & - & 一 & 一 \\
\hline $\begin{array}{l}\text { DPPD, } \\
25^{\circ} \mathrm{ppm}\end{array}$ & - & - & - & I I $/$ I I & $5 \cdot 9 \pm I \cdot 4(3)$ & $7 \cdot 8 \pm I \cdot I(2)$ \\
\hline
\end{tabular}

* Total number of chicks in denominator; number with exudative diathesis in numerator.

$\dagger$ Results are given as means with standard deviations and the number of tests (on paired livers) is shown in parentheses.

$\mp$ Results are given as means with standard deviations and the number of chicks is shown in parentheses.

$\S$ Significantly lower than results for either no supplement or $\mathrm{Se}(P<0.01)$. In addition, the results for chicks given vitamin $\mathrm{E}$ are significantly lower than for those not given vitamin $\mathrm{E}(P<0.0 \mathrm{r})$.

Expt 9. This experiment demonstrated the ease with which the total PUFA content of liver and adipose tissue of vitamin E-deficient rats could be altered by giving them small doses of methyl linoleate over a relatively short period of time.

Rats were given the vitamin E-deficient diet $\mathrm{A}_{1} \mathrm{OY}_{3}$ (Bunyan, McHale \& Green, I963) from I4 days to 6 months old. They were then given five to fifteen daily oral doses (by blunt dosing needle) of $0.5 \mathrm{ml}$ methyl oleate or methyl linoleate. In I-2 weeks, liver PUFA rose by $28 \%$, while the value for adipose tissue was more than doubled (Table 6). 
Table 6. Expt 9. Accumulation of polyunsaturated fatty acids (PUFA) in tissues of 6-month-old vitamin E-deficient rats given methyl linoleate or methyl oleate

(Results are given as mean values $(\mathrm{mg} / \mathrm{g})$ with standard deviations and the number of rats is shown in parentheses. A sample of each rat liver was extracted and portions of the extract were saponified and tested)

\begin{tabular}{|c|c|c|c|c|}
\hline \multirow[b]{2}{*}{ Tissue } & \multirow[b]{2}{*}{ Sex } & \multirow{2}{*}{$\begin{array}{l}\text { daily doses } \\
(0.5 \mathrm{ml} / \text { dose })\end{array}$} & \\
\hline & & & Methyl linoleate & Methyl oleate \\
\hline \multirow[t]{5}{*}{ Liver } & Female & 5 & I3.0 $1 x_{4}(2)^{*}$ & $8 \cdot 6 \pm 0(2)$ \\
\hline & Male & Io & $19.0 \pm 0.6(2)$ & $15 \cdot 1 \pm 1 \cdot 7(2)$ \\
\hline & Male & I I & $17 \cdot 3 \pm 2.6(3)$ & $14.0 \pm 3.1(3)$ \\
\hline & Male & I 5 & II. $4 \pm 1 \cdot 4(2)$ & $9 \cdot 2 \pm 1 \cdot 0(2)$ \\
\hline & & Mean & $15 \cdot 4^{*}$ & $12 \cdot 0$ \\
\hline Adipose tissue & Male & Io & $53 \pm 6(2) \dagger$ & $22 \pm 2(3)$ \\
\hline
\end{tabular}

* Significantly higher than the control value $(P<0.01)$, allowing for variance between experiments.

+ Significantly higher than control $(P<0.01)$.

\section{DISCUSSION}

It is known that there are certain specific effects of vitamin $\mathrm{E}$ deficiency on PUFA composition in some tissues under some conditions. Thus, Hove \& Hove (r953) showed decreases of $4 \mathrm{I} \%$ and $12 \%$, respectively, in the linoleate content of vitamin E-deficient rabbit and rat brain although there were no changes in the linoleate content of liver and carcass nor in the arachidonate content of the three tissues. Bhalerao, Kokatnur \& Kummerow ( 1962 ) found that vitamin $\mathrm{E}$ increased $\mathrm{C}_{20}$ and higher fatty acids in the brains of chicks given maize oil, although liver was not affected. The studies of Bieri \& Andrews (I964) on vitamin E deficiency in rats showed little or no changes in PUFA composition of liver, heart and kidney, but there was a marked decrease in docosapentaenoate in testis and smaller rises in linoleate, arachidonate and docosatetraenoate. These authors suggested that vitamin $\mathrm{E}$ deficiency inhibited the conversion of arachidonate into docosapentaenoate. Carpenter (1966) reached a similar conclusion from studies on the development of rat testes, and Davis \& Coniglio (1966) suggested that docosapentaenoic acid fulfilled a specific structural need in the spermatid and spermatozoon. In addition to inhibition of conversion of arachidonate into docosapentaenoate, vitamin $\mathrm{E}$ deficiency has also been found to result in increased synthesis of arachidonate in rat liver (Bernhard, Lindlar, Schwed, Vuilleumier $\&$ Wagner, I963) and in chick liver (Gilliam \& McCay, rg66).

Our experiments demonstrate that deficiency of vitamin $\mathrm{E}$ did not depress the total PUFA content of rat liver, kidney, heart, spleen, brain, adrenal and adipose tissue. Similarly, there was no decrease in PUFA in the livers of rats subjected to a deficiency of Se or vitamin $\mathrm{E}$ and $\mathrm{Se}$ in short-term and long-term experiments, even though there was a high incidence of liver necrosis in both. Liver PUFA was not depressed in chicks developing exudative diathesis due to a deficiency of vitamin $\mathrm{E}$ and Se. However, when rats were given a vitamin E-deficient diet containing $8 \%$ oxidized codliver oil for a long period, there was a severe loss of PUFA from leg muscle but not from kidney or adipose tissue from the same animals. 
This large decrease in PUFA content of rat skeletal muscle is consistent with the finding, by Witting \& Horwitt (1964), of lower total PUFA in muscle phospholipids of vitamin E-deficient rats given dietary fats of varying degrees of unsaturation. Earlier work by Hove \& Seibold (1955) had also shown decreased proportions of linoleate, arachidonate and pentaenoate in the muscle of pigs suffering from a type of liver necrosis. Witting \& Horwitt (1966) confirmed the progressive net decrease in the higher PUFA of rat muscle (and liver and testis) and also found a net increase in arachidonate in all three tissues. Witting \& Horwitt (1966) found increased synthesis of the higher PUFA, interpreting this as a homoeostatic response to peroxidative loss. However, our findings suggest that the concept of generalized peroxidative loss is too simple to explain the complexity of the changes that take place.

We wish to thank Miss R. J. Castle and Miss E. A. Murrell for their technical assistance.

\section{REFERENCES}

Bernhard, K. (1958). Oleagineux $\mathbf{1 3}, 19$.

Bernhard, K., Lindlar, F., Schwed, P., Vuilleumier, J.-P. \& Wagner, H. (1963). Z. Ernährungwiss 4, 42.

Bieri, J. G. \& Andrews, E. L. (1964). Biochem. biophys. Res. Commun. x7, I 5.

Bhalerao, V. R., Kokatnur, M. G. \& Kummerow, F. A. (1962). Fedn Proc. Fedn Am. Socs exp. Biol. 2r, 290.

Bunyan, J., Diplock, A. T., Edwin, E. E. \& Green, J. (1962). Br. F. Nutr. 16, 519.

Bunyan, J., Green, J. \& Diplock, A. T. (1963). Br. F. Nutr. 17, i I 7.

Bunyan, J., Green, J., Diplock, A. T. \& Robinson, D. (1967a). Br. F. Nutr. 21, 137.

Bunyan, J., Green, J., Diplock, A. T. \& Robinson, D. (1967b). Br. F. Nutr. 21, 147.

Bunyan, J., McHale, D. \& Green, J. (1963). Br. F. Nutr. 17, 39 r.

Carpenter, M. (1966). Fedn Proc. Fedn Am. Socs exp. Biol. 25, 764.

Century, B. \& Horwitt, M. K. (I960). F. Nutr. 72, 357.

Davis, J. T. \& Coniglio, J. G. (1966). Fedn Proc. Fedn Am. Socs exp. Biol. 25, 765.

Diplock, A. T., Bunyan, J., McHale, D. \& Green, J. (1967). Br. F. Nutr. 2x, 103.

Folch, J., Lees, M. \& Stanley, G. H. S. (1957). F. biol. Chem. 226, 497.

Gilliam, J. M. \& McCay, P. B. (1966). Fedn. Proc. Fedn Am. Socs exp. Biol. 25, 24 I.

Green, J., Diplock, A. T., Bunyan, J., McHale, D. \& Muthy, I. (1967). Br. F. Nutr. 21, 69.

Hove, E. L. \& Hove, Z. (1953). Fedn Proc. Fedn Am. Socs exp. Biol. 12, 417.

Hove, E. L. \& Seibold, H. R. (1955). F. Nutr. 56, 173.

MacGee, J. (1959). Analyt. Chem. 31, 298.

Pritchard, E. T. \& Singh, H. (1960). Biochem. biophys. Res. Commun. 2, I84.

Witting, L. A. \& Horwitt, M. K. (1964). F. Nutr. 82, i 9.

Witting, L. A. \& Horwitt, M. K. (1966). Fedn Proc. Fedn Am. Socs exp. Biol. 25, 24 I. 